\title{
STUDY OF SOME DIFFERENT BIOLOGICAL ACTIVITIES FOR RIND, FLESH AND SEEDS OF PUMPKIN RIPE FRUITS (Cucurbita pepo L.) AND CHARACTERIZE THEIR NATURAL ORGANIC COMPOUNDS \\ Badr, Sh.E.A.; Hanan M.A. El Ghandour; W.H. M. El-Reffaei and Gehan M. El- Moghazy. \\ Regional Center for Food and Feed (RCFF), Agricultural Researches Center, Giza, Egypt. \\ e-mail: sherif2badr@yahoo.com.
}

\begin{abstract}
GC-MS analysis of the extract's unpolar fraction revealed the existence of dodecane and tetradecane. Structures of the isolated compounds (1 6) were fixed by NMR \& El- MS spectroscopy, and GC-MS analysis. Chemical analysis of fiber, protein, $\beta$-carotene, carbohydrates, minerals and amino acids present in rind, flesh and Defatted Seeds Meal "DSM", were investigated. Extracts of the two constituted fractions of pumpkin (Rind and flesh) were consequently examined for In vitro cytotoxicity against the tumor cell lines each of Cervical carcinoma (HELA), Colon carcinoma (HCT116) and Intestinal carcinoma (CACO). The amino acids score for DSM of Pumpkin where; the phenylalanine and lysine were the first limiting amino acids, Tryptophan was the second limiting amino acid and phenylalanine was the third limiting amino acid. In vivo the protein quality of the Pumpkin DSM was assayed by animal feeding experiments and the data of the nitrogen balance is reported. Mixing Pumpkin Rind, Flesh and Seeds extracts with pan bread raw materials showed a positive effects as antifungal as it could increase the shelf life of the pan bread before the onset of fungal spoilage.

Keywords: GC-MS, NMR and EI- MS spectroscopy, Chemical composition, In vitro cytotoxicity, In vivo animal feeding, Amino acids score, shelf life, Ban bread, Fungal spoilage.
\end{abstract}

\section{INTRODUCTION}

Growth of some fungal strains in starchy and highly carbohydrate content food is considered as a very alarming subject that can cause health hazard concerning the large number of the fungal spores as well as the serious effect caused by its metabolites (mycotoxins). Addition of Pumpkin Rind, Flesh and Seeds to the raw materials during pan bread preparation is considered as a good trial for controlling the hazards caused by moulds which not only threaten human health but also negatively affect the quality of such bread.

Animal feeding experiment with rats considered by the $\mathrm{FAO} / \mathrm{WHO}$ expert consultation committee meeting on protein quality evaluation held in Bethesda, MD, USA as the most suitable practical method for predicting protein digestibility in humans (Eggum, 1991) is widely used for the evaluation of protein quality in various foods. However, the rats may have a higher requirement for sulphur amino acids than humans. Besides, 
requirement of histidine, isoleucine, threonine and valine for rats are also higher (Eggum, 1991) .

C S, NCl (2004) mention that, Over a 33 year period $(1970-2003)$ more than 300,000 new patients visited the $\mathrm{NCl}$, \& in excess of one million outpatient visits. In the year 2004 there were; 19,210 new patients seen at the $\mathrm{NCl}, 14,000$ hospital admissions, approximately 170,000 outpatient visits, $65 \%$ of patients came from the Greater Cairo area, 16\% from lower Egypt, \& $20 \%$ from upper Egypt, $48 \%$ of cases were males, approximately $87 \%$ of patients are treated free of charge. The food we eat provides our bodies with nutrients necessary for cellular replication, repair and maintenance. Proponents of nutrition therapy or special diets maintain that certain types of food or specific combinations of food can prevent illness and facilitate recovery from disease. In addition, many non-Western cultural traditions do not distinguish between medicine and food, considering food as medicine. Special diets include macrobiotics, Gerson and vegetarianism. It is highly recommended that anyone who's been diagnosed with cancer and wants to be proactive in helping overcome their problem, that they turn to a mainly alkaline food intake as opposed to acid food. Every food item we eat is classified as either alkaline or acid and a recommended ratio is 80 percent of our intake should be alkaline with the other 20 percent can be acid. An acidic body will also decrease the body's ability to absorb minerals and other nutrients which are essential in maintaining our health. A high acid intake is known to cause ill health, including diseases such as cancer as well as early aging. But when an ideal ratio is maintained, the body has a strong resistance against all diseases and can also help you return to health. While cancer has many causes the most influential cause is what we eat everyday because the state of our health is directly related to our dietary choices. Our diet has changed over the last 50 years and most of what we eat is now available in supermarkets and supermarkets have an overwhelming influence on what we buy. Much of what's available in supermarkets is processed and because of its processing is low in nutritional value and that is without question, the reason why there is so much cancer now.

Pumpkin is one of 200 Species, exhibiting hypoglycaemic properties, and hence represents as sources of antidiabetic drugs (Jia Wei et al., 2003).

Pumpkin, is one of the medicinal herbs which were meticulously organized in these antidiabetic drug formulas as they are rich with polysaccharide, which play an important role to restore the functions of pancreatic tissues and cause an increase in insulin output by the functional beta cells, while other ingredients enhance the microcirculation, increase the availability of insulin and facilitate the metabolism in insulin-dependent processes (Jia Wei et al., 2003). Pharmacological and clinical evaluations indicated that these drugs had a mild, but significant, blood glucose lowering effect and that the long-term use of these agents may be advantageous over chemical drugs in alleviating some of the chronic diseases and complications caused by diabetes. Additionally, the use of these natural agents in conjunction with conventional drug treatments, such as a chemical agent or insulin, permits the use of lower doses of the drug and/or decreased frequency of administration which decreases the side effects most commonly 
observed (Jia Wei et al., 2003). Pumpkin Flesh is a low acid vegetable and requires special attention to preparation and processing (Brian, 2002), at the fully matured stage, flesh varied in color as several shades of yellow, deep yellow to orange with $2-5 \mathrm{~cm}$ thick flesh and total carotenoids ranged from $2.34 \mathrm{mg}$ to $14.85 \mathrm{mg}$ with a population mean of $9.29 \mathrm{mg} / 100 \mathrm{~g}$ of fresh weight (Sudhakar, et al., 2003). Carotenoids are a class of natural fat-soluble pigments found principally in plants, algae, and photosynthetic bacteria, where they play a critical role in the photosynthetic process. They also occur in some non-photosynthetic bacteria, yeasts, and molds, where they may carry out a protective function against damage by light and oxygen. Carotenes or Carotenoids are a yellow-orange pigment. Carotene, mostly as $\beta$-carotene is used in many foods as a coloring additive (Britton et al., 1995).

The current study has multi objectives of study the biological effects as antitumor and preserved agent for the extracted pumpkin items as well as studies the protein quality of the Defatted pumpkin Seeds Meal "DSM".

\section{MATERIALS AND METHODS}

\section{Sampling:}

Pumpkin Collection:

Pumpkin ripe fruits were purchased and collected from different markets of eleven governorates; Cairo, Giza, Kalubia, Helwan and 6- October "Great Cairo", Alexandaria, El- Behaira, Dakkahlia, Marsa Matrouh, Beni-Swif and Assuit with selection of the full- colored mature pumpkin with fine texture.

\section{Rind, Seeds and Flesh Pre- treatment:}

Fruits were washed with tap water, dried and pealed to isolate the rind from the flesh according to (Brian, 2002) and (Gouado et al., 2007) and remove the seeds from the flesh. Rind was dried on $40^{\circ} \mathrm{C}$ overnight with stirring and handly crushed to give bran. As in (Brian, 2002), seeds were washed to remove the clinging fibrous pumpkin tissues, dried in the sun for three days with frequently stirring then, hulls were removed manually to obtain the cotyledons as the methodology of (Yusuf et al., 2007) and (Sara et al., 2008). The seeds were ground to a fine powder and then dried for $2 \mathrm{hrs}$ at $100^{\circ} \mathrm{C}$ and defatted by extraction the pumpkin seeds oil and the defatted meal dried in oven at $60^{\circ} \mathrm{C}$ for four hours.

According to (Mohamed et al., 2003), flesh of Pumpkin was sliced into $2 \mathrm{~mm}$ thickness and dried in the indirect type solar drying system using forced circulation in the Solar Energy Department of National Research Center. The total moisture contents for Rind, Flesh and Seeds of pumpkin were estimated in the beginning as the method previously described by (AOAC, 1980).

Chemical analysis:-

Ingredients analysis:

Crude protein and fat according to (AOAC, 2000); were estimated to Rind, Flesh and Defatted Seeds Meal (DSM) extracts of pumpkin. According to (Sara et al., 2008) carbohydrate content was estimated by difference. 
Badr, Sh.E.A. et al.

Estimation of minerals \{calcium, iron, zinc, copper and Selenium\} in Rind, Flesh and DSM by inductive coupled plasma ICP "optima 2000" according to (AOAC, 2002) and ( Iva et al., 2003).

\section{Estimation of $\beta$ - carotene:}

According to (Leth and Jacobsen, 1993), $\beta$ - carotene in both rind and Flesh of Pumpkin was determined.

Extraction, Determination and Characterization of Natural organic compounds present in Pumpkin Rind and Flesh:-

\section{Rind Extract:}

$100 \mathrm{~g}$ of the dried and grinded Rind were subjected to exhaustive extraction by methanol $(1.2 \mathrm{~L})$ during soaking for several times.

After a complete extraction and concentration under reduced pressure at low temperature $\left(45^{\circ} \mathrm{C}\right)$, the respite water extract was applied to extraction with chloroform. After complete extraction, the chloroform layer was evaporated in vacuo to dryness affording an oily orange extract $(4.1 \mathrm{~g})$. The methanol crude extract of Rind was applied to detailed biological and chemical studies.

\section{Flesh Extract:}

The dried interior part of pumpkin (flesh) was applied to grinding. Such dried flesh powder $(250 \mathrm{~g})$ was applied to exhaustive extraction by methanol $(2 \mathrm{~L})$ during its soaking for several times. After full extraction, the methanol extract was concentrated in vacuo at $45^{\circ} \mathrm{C}$, and the remaining water residue was applied to extraction with chloroform. The chloroform extract was then evaporated to dryness in vacuo, affording an oily orange crude extract $(7.3 \mathrm{~g})$. The methanol crude extract of flesh was applied to detailed biological and chemical studies.

Isolation of the Bioactive Compounds Obtained from Rind and Flesh Extracts:

According to TLC monitoring, both obtained oily orange crude extracts from flesh $(7.3 \mathrm{~g})$ and rind $(4.1 \mathrm{~g})$ exhibited their high similarity, and combined. The combined crude extract was divided into four fractions using Sephadex LH-20 (DCM/40\%MeOH) after TLC monitoring; FI (3.55 g), FII (2.2 g), FIII $(3.82 \mathrm{~g})$ and FIV $(1.78 \mathrm{~g})$. The first fast fraction I was oily (KSPU1) and estimated by GC-MS analysis. A silica gel column chromatography $(100 \times 2$ $\mathrm{cm}$ ) of the second fraction (II) and elution with cyclohexane-DCM gradient delivered two oily components; KSPU2 (1, $309 \mathrm{mg})$ and KSPU4 (3, $220 \mathrm{mg})$. Components KSPU2 and KSPU4 are UV absorbing, turned blue on spraying with anisaldehyde/sulphuric acid. From the middle polar fraction III, two colourless crystals of calotropoleanyl ester (4; KSPU6: $2.20 \mathrm{~g}$ ) and cholesterol (5; KSPU8: $1.20 \mathrm{mg}$ ) were obtained during silica gel column (100 $\times 2 \mathrm{~cm}$ ) and elution with $\mathrm{DCM}-\mathrm{MeOH}$, followed by a purification using a Sephadex $\mathrm{LH}-20$ column (DCM/40\% MeOH). Finally, purification of fraction IV starting with silica gel column $(100 \times 2 \mathrm{~cm}$, DCM-MeOH), followed by purification on Sephadex LH-20 column (DCM/40MeOH), 13(18)-oleanen-3ol (6; KSPU7: $322 \mathrm{mg}$ ) was afforded as colourless crystals.

\section{Experimental Section:}

The NMR spectra were measured on a Bruker AMX 300 (300.135 $\mathrm{MHz})$, a Varian Unity $300(300.145 \mathrm{MHz})$ and a Varian Inova 600 (150.820 
$\mathrm{MHz}$ ) spectrometer. El mass spectra were recorded on a Finnigan MAT 95 spectrometer $(70 \mathrm{eV})$ with perfluorkerosine as reference substance for EI HRMS. GC-MS was used as Trace GC-MS Thermo Finnigan, ionization mode El eV 70, instrument equipped with a capillary column CP-Sil $8 \mathrm{CB}$ for amines (length : $30 \mathrm{~m}$; inside diameter: $0.25 \mathrm{~mm}$; outside diameter: $0.35 \mathrm{~mm}$; film thickness: $0.25 \mu \mathrm{m}$ ). The analysis was carried out at a programmed temperature: initial temperature $40^{\circ} \mathrm{C}$ (Kept for $1 \mathrm{~min}$ ), then increasing at a rate of $10^{\circ} \mathrm{C} / \mathrm{min}$ and final temperature $280^{\circ} \mathrm{C}$ (kept for $10 \mathrm{~min}$ ), Injector temp was $250{ }^{\circ} \mathrm{C}$ and detector (mode of ionization: El) temperature was $250{ }^{\circ} \mathrm{C}$, He was a carrier gas at flow rate $1 \mathrm{ml} / \mathrm{min}$, total run time $27 \mathrm{~min}$ and Injection volume $0.2 \mu \mathrm{L}$.

\section{Defatting Seeds Yeild:}

The residue Powder of the pumpkin seeds oil extraction process with petroleum ether was exposured to Lab. temperature for three days and placed in oven of $60{ }^{\circ} \mathrm{C}$ to complete evaporation and getting ride of the remnant solvent and its odor. Estimation of the chemical constituents and evaluation of the biological activities were carried out for this harvest "Defatted seeds meal DSM" on a broad scale.

Determination of Amino acids:

Amino acids determination for "Defatted seeds meal "DSM" was performed according to method of the (AOAC, 2005). Oxidation with performic acid, to protect methionine and cystine from distraction during acid hydrolysis with $(6 \mathrm{M} \mathrm{HCL})$ were carried out in closed conical flask for determine all amino acid other than tryptophan. Sample of $20-30 \mathrm{mg}$ weighted in conical flask and $5 \mathrm{ml}$ of performic acid was added. The flask was closed and placed in ice water bath for $16 \mathrm{hr}$. Sodium metabisulfate and $25 \mathrm{ml} \mathrm{HCL} 6 \mathrm{~N}$ were added to the oxidized mixture. The flask was placed in an oven at $110^{\circ} \mathrm{C}$ for $24 \mathrm{hr}$. The flask was then opened and all removed by evaporating samples to dryness in rotary evaporator. A suitable volume of sodium citrate puffer ( $\mathrm{pH}$ 2.20) was added to the dried film of hydrolyzed sample. After all soluble material completely dissolved, the samples analyzed for amino acids using Eppendorf LC 3000 (EZ Chrom, software used for data collection and processing). The results were calculated as percentage of total crude protein. Determinate tryptophan was carried out using method described by Miller, 1967 after hydrolysis of samples with barium hydroxide.

\section{Biological Activities for Rind, Flesh and Seeds of Pumpkin.}

In vitro cytotoxic activity for Rind and Flesh Extracts using SRB assay:

These estimations were carried out and documented in the Cancer Biology Department, Pharmacology Unit, National Cancer Institute, Cairo University. Potential cytotoxicity by Sulpho Rodamine B assay for the Rind extract and pumpkin seed oil were tested in vitro using the method of (SKehan et al., 1990) on each of HELA (cervix carcinoma cell line), HCT116 [Colon carcinoma cell line] and CACO [Intestinal carcinoma cell line]. Cells were plated in 96 - multiwell plate $\left(10^{4}\right.$ cells/well) for 24 hours before treatment with the compounds to allow attachment of cell to the wall of the plate. Different concentrations of the two compounds (Flesh and Rind) under test $(0$, 
Badr, Sh.E.A. et al.

5.0, 12.5, 25.0, and 50) $\mu \mathrm{g} / \mathrm{ml}$ ) were added to the cell monolayer triplicate wells were prepared for each individual dose. Monolayer cells were incubated with the two compounds for 48 hours at $37^{\circ} \mathrm{C}$ and in atmosphere of $5 \% \mathrm{CO}_{2}$. After 48 hours, cells were fixed, washed and stained with SRB stain. Excess stain was washed with acetic acid and attached stain was recovered with tris EDTA buffer. Color intensity was measured in an ELISA reader. The relation between surviving fraction and drug concentrations is plotted to get the survival curve of each tumor cell line after the specified compound.

In vivo Protein Quality for Pumpkin Defatted Seeds Meal.

Net protein utilization (NPU), Biological Value (BV) and the true digestibility (TD) for defatted pumpkin seeds meal were evaluated with male sprague- Dawley rats. Groups of five rats weighing between 75 and $80 \mathrm{~g}$ were weighed at the beginning of the experiment and divided into groups. The mean weight of the groups differed by no more than $1.0 \mathrm{~g}$. The rats were housed individually in cages at $25^{\circ} \mathrm{C}$ of temperature and $50 \%$ of relative humidity. Daily food was restricted to $10 \mathrm{~g}$ of dry matter. Water was provided ad libitium. The experiment period was 9days, with 4 days for adaptation. Feed residues, urine and feces were collected during a 5 days balance period. Urine and feces were collected in $5 \%$ sulphuric acid and assayed for nitrogen by the method of Kjeldahl. True protein digestibility, biological value and net protein utilization were calculated using the Thomas- Mitchell's equations as described by (Eggum, 1973). Corrections were made for the endogenous excretion of $\mathrm{N}$ in feces $(77.1 \mathrm{mg} \mathrm{N} / 5 \mathrm{~d} / \mathrm{rat})$ and in urine $(76.9 \mathrm{mg} \mathrm{N} / 5 \mathrm{~d} / \mathrm{rat})$. The reference diet was made with casein (casein ANRC 30M) $10 \%$ supplemented with L- methionine $0.22 \%$ of the total solids of the diet. The diets contained $10 \%$ sucrose $69 \%$ maize starch, cellulose $5 \%$ maize oil $5 \%$ mineral blend $4.8 \%$, vitamin $0.8 \%$ and choline chloride $0.2 \%$. In the experimented diet, the protein from casein was substituted with equivalent amount of protein from defatted pumpkin seeds meal.

Validity of Pumpkin Rind and Flesh Extracts as Preserved Natural Organic Compounds.

Pan Bread Preparation.

The backing of pan bread was carried out in Backing Research Lab., Food Technology Research Instiute (FTRI).

The ingredients of Pan Bread consisted of $100 \mathrm{~g}$ fortified wheat flour, $5.0 \mathrm{~g}$ corn oil, $5.0 \mathrm{~g}$ sugar, $1.0-1.5 \mathrm{~g}$ baking yeast, $1.0 \mathrm{~g}$ sodium chloride salt, $1.0 \mathrm{~g}$ improfier, and $18.0 \mathrm{~g}$ water. All the last ingredients except water were mixed in a dough mixer using the flat beater for 3 minutes include water addition. Long cut of paste pieces were done. The Pan breads were baked at 100 to $110^{\circ} \mathrm{C}$ for $12 \mathrm{~min}$. (Wade, 1988). Control Pan bread sample was proceeded by the same procedure while, $5.0 \mathrm{ml}$ Rind extract and $5.0 \mathrm{ml}$ Flesh extract instead of equal volumes of used water were added individually to the other ingredients to give two types of fortified Pan breads.

The prepared pan bread subsamples which were mixed with Pumpkin Rind and Flesh in the above mentioned ratios, were stored at room temperature for 12 days after which total fungal count was performed according to (NMKL, 2005) as follows:- 
a- Five grams of each treated pan bread sample were mixed individually with $4.5 \mathrm{ml}$ of sterile saline solution from which ten folds serial dilutions were prepared.

b- One $\mathrm{ml}$ from each dilution was inoculated in a sterile petridish in which about $10-15 \mathrm{ml}$ of Chloramphenicol Rose Bengal agar were poured after solidification, the plates were incubated at $25{ }^{\circ} \mathrm{C}$ for 5-7 days after which all colonies were countered in the plate of the dilution which gives total numbers between 10- $100 \mathrm{cfu}$.

c- Total fungal count is calculated as the obtained cfu number multiplied by the dilution factor.

\section{RESULTS \& DISCUSSION}

\section{Chemical Composition of Rind, Flesh and Seeds Extracts of Pumpkin:}

As comparative study in the chemical composition for the pumpkin fruit constituents; Rind, Flesh and Seeds, the moisture contents were estimated as $84.18 \% \pm 1.42,92.93 \% \pm 1.01$ and $43.29 \% \pm 4.38$, respectively. The ash contents reflected the high degree of mineral amounts (Hamed et al., 2008) therefore, high ash in rind and Defatted Seeds Meal (DSM) of pumpkin $(10.65,09.16)$ are expected to be rich in the studied minerals; Calcium, Iron, Zinc, Copper and Selenium while; it was (6.64) lower value in flesh (Table 1). Based on fat contents, the flesh and rind were poor (0.18 and $06.57 \%)$. Defatting of the seeds delivered higher content of fats (1.41\%) in DSM than reported by (Giami et al., 2005), and raised the protein content to $70.15 \%$. This pointed to DSM as an excellent source of proteins and minerals. Contrarily, rind and flesh have lower extents of protein (23.95 and $15.50 \%)$. Flesh bears high value of carbohydrate $(48.40 \%)$ than rind $(19.45 \%)$ and DSM (9.53\%). Finally, Rind, Flesh and DSM of Pumpkin are talented sources of minerals.

Table 1: Chemical constituents for Rind, Flesh and DSM of Pumpkin (g/100g dry sample):-

\begin{tabular}{|l|c|c|c|}
\hline \multicolumn{1}{|c|}{ Ingredient } & Pumpkin Rind & Pumpkin Flesh & DSM \\
\hline Ash & 10.65 & 06.64 & 09.16 \\
\hline Fat & 06.57 & 00.18 & 01.41 \\
\hline Fiber & 29.62 & 11.25 & 07.12 \\
\hline Moisture & 09.76 & 18.03 & 02.63 \\
\hline Protein & 15.50 & 70.15 \\
\hline Carbohydrates & 23.95 & 48.40 & 09.53 \\
\hline \multicolumn{3}{|l|}{} \\
\hline Minerals (ppm) & 19.45 & 3662.00 & 0617.40 \\
\hline Ca $^{++}$ & 5571.00 & 0091.33 & 0219.67 \\
\hline $\mathrm{Fe}^{++}$ & 0247.30 & 0320.50 & 0131.12 \\
\hline $\mathrm{Zn}^{++}$ & 0042.92 & 0016.25 & 0035.77 \\
\hline $\mathrm{Cu}^{++}$ & 0012.91 & 0014.00 & 0018.04 \\
\hline $\mathrm{Se}^{++}(\mathrm{ppb})$ & 0012.71 &
\end{tabular}


Badr, Sh.E.A. et al.

\section{$\boldsymbol{\beta}$ - Carotein of Rind and Flesh:}

Pumpkin represents an ideal source of carotenoids, the latter play an important role as sources of provitamin A and as antioxidants (Gouado et al., 2007). The level of vitamin A was calculated in different fruits, at where $1 \mu \mathrm{g}$ of vitamin $A$ is supplied by $12 \mu \mathrm{g}$ of $\beta$-carotene (West et al., 2002). Estimation of $\beta$-carotene in pumpkin using HPLC recognized its localization in all constituents (Table 2); at where flesh was recorded to be the most abundant source of $\beta$-carotene $(3934.02 \mu \mathrm{g} / 100 \mathrm{~g}$ of dry weight), in higher extent than reported by (Gouado et al., 2007). On the other hand, rind was of a moderate abundance of $\beta$-carotene $(751.99 \mu \mathrm{g} / 100 \mathrm{~g})$. To prolong consumption of $\beta$ carotene and vitamin A-rich pumpkin, it is recommended to preserve the fruit according to candying and picklinge method (Chavasit et al., 2002).

Table 2: $\beta$ - Carotene contents in dry samples of Pumpkin rind \& flesh.

\begin{tabular}{|c|c|c|}
\hline \multirow{2}{*}{$\begin{array}{c}\text { B- Carotene content } \\
(\mu \mathrm{g} / 100 \mathrm{~g})\end{array}$} & Rind & Pumpkin items \\
\cline { 2 - 3 } & 751.99 & 3934.02 \\
\hline
\end{tabular}

\section{Amino acids of Defatted Seeds:}

DSM of Pumpkin represents promising sources of protein with various ratios (Table 3). The whole contents of amino acids (\%) in DSM were 52.77, exemplifying in 17 amino acids. DSM reported the most talent source of proteins, in which glutamic was the central amino acid (11.50\%), followed by aspartic acid (05.59\%) and arginine (05.42\%). The first limiting amino acid was lysine for pumpkin seed (El-Adawy and Taha, 2001). The last results were matched with those reported in literature (EL-Soukkary, 2001 and Zhu et al., 2006)

Table 2: Amino acid composition for Defatted Seeds Meal (mg/ 100mg dry sample) (\%):

\begin{tabular}{|c|c|}
\hline Ingredient & Defatted Seeds Meal \\
\hline Aspartic acid (Asp.) & 05.59 \\
\hline Threonine (Thr.) & 01.79 \\
\hline Serine (Ser.) & 02.87 \\
\hline Glutamic acid (Glu.) & 11.50 \\
\hline Proline (Pro.) & 02.23 \\
\hline Glycine (Gly.) & 02.85 \\
\hline Alanine (Ala.) & 02.56 \\
\hline Valine (Val.) & 02.61 \\
\hline Isoleucine (Iso.) & 02.04 \\
\hline Leucine (Leu.) & 04.15 \\
\hline Phenyl alanine (Phe.) & 03.05 \\
\hline Histidine (His.) & 02.00 \\
\hline Lysine (Lys.) & 01.90 \\
\hline Arginine (Arg.) & 05.42 \\
\hline Cystine (Cys.) & 00.63 \\
\hline Methionine (Meth.) & 01.18 \\
\hline Tryptophan (Tyr.) & 00.40 \\
\hline Total & $52.77 \%$ \\
\hline
\end{tabular}




\section{Chemical assays for Rind and Flesh:- \\ Isolation and Structural Characterization of Flesh and Rind Extracts:-}

The two aqueous orange crude extracts of rind and flesh were consequently applied here to a water suspension followed by individual extraction with chloroform, and concentration in vacuo. TLC evaluation of both extracts visualized by detection under UV and spraying with anisaldehyde/sulphuric acid, recognized their likeness in the constituted components. Both extracts displayed major unpolar orange bands characteristic for carotenes as they turned blue on treatment with conc. sulphuric acid. Furthermore, both extracts exhibited several UV nonabsorbing bands for low and middle polar components, were detected as pink-violet and/or blue on spraying with anisaldehyde/sulphuric acid. This pointed to terpenoidal and/or steroidal and fatty acids components.

\section{GC-MS Analysis:-}

As alternative confirmation for the similarity of both organic extracts from rind and flesh, they were individually applied to GC-MS analysis. In accordance, both extracts exhibited high relationships in their constituents. The most abundant detected components in extracts were identified as hexa decanoic acid methyl ester (RT: 19.61; MW: 270; MF: $\mathrm{C}_{17} \mathrm{H}_{34} \mathrm{O}_{2}$ ), and hexa decanoic acid (RT: 19.95; MW: 256, MF: $\mathrm{C}_{16} \mathrm{H}_{32} \mathrm{O}_{2}$ ). GC-MS analysis of the remaining visible peaks established unknown compounds, which are still under investigation.

Chemical GC-MS assays for organic extracts of the main fruit parts, rind and flesh, established their unique constituents. Chromatographic purification of the extract afforded triglyceride fatty acid mixture (1), tetrahydro-thiophene (2), linoleic acid (3), calotropoleanly ester (4), cholesterol (5) and 13[18] oleanen-3-ol (6).<smiles>[R]C(=O)O[C@H]([2H])[C@@H](OC([R])=O)[C@@H]([2H])OC(=O)P</smiles>

(1)<smiles>O=S1(=O)CCCC1</smiles><smiles>C/C=C\CCCCCCCCCCCCC(=O)O</smiles>

(2)

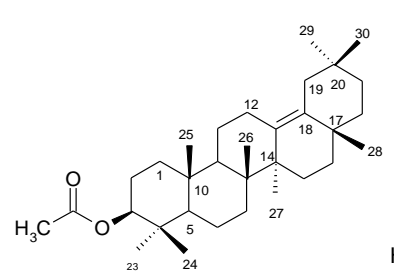

(4)

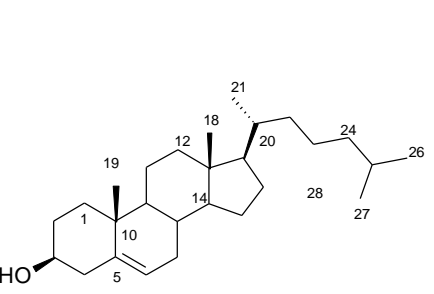

(5)

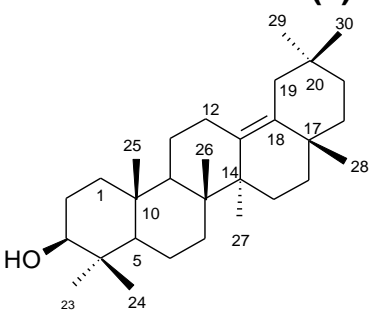

(6) 
Badr, Sh.E.A. et al.

GC-MS analysis of the extract's unpolar fraction revealed the existence of dodecane and tetradecane. Structures of the isolated compounds (1-6) were fixed by NMR and El MS spectroscopy, and GC-MS analysis as previously discussed.

\section{Isolation and structural elucidation of the entire constituents of Rind} and Flesh Extracts:-

As the similarity of both extracts obtained from rind and flesh, they were combined and applied to purification during a series of chromatographic techniques. The extract was first applied to fractionation during Sephadex LH-20 column and eluted with $(\mathrm{DCM} / 40 \% \mathrm{MeOH})$ gradient. Based on the TLC monitoring visualized by UV detection and spraying with anisaldehyde/sulphuric acid, four fractions were yielded (FI, FII, FIII and FIV). TLC of the first fast fraction I established its oily nature (KSPU1), which was assigned by GC-MS analysis, affording dodecane (RT: 10.76, MF: $\mathrm{C}_{12} \mathrm{H}_{14}$ ), tetrahydro-thiophene (2, RT: 11.02) and tetradecane (RT: 13.56, MF: $\left.\mathrm{C}_{14} \mathrm{H}_{16}\right)$. A silica gel column chromatography of the second fraction (II) eluted with cyclohexane-DCM, led to two oily components; KSPU2 (1) and KSPU4 (3). Both components were UV absorbing and stained as blue on spraying with anisaldehyde/sulphuric acid, which were finally deduced as triglyceride fatty acid mixture (1) and Linoleic acid (3), respectively.

\section{Triglyceride Fatty Acid Mixture}

${ }^{1} \mathrm{H}$ NMR spectra of KSPU2 (1) displayed three multiplet signals at two regions of $\delta 5.43-25$ and 4.37-4.00, representing olefinic methines and $s p^{3}$. oxymethines/methylenes, respectively. Rather multiplet signals located between $\delta$ 2.80-0.97 are characteristic to different methylene chains, ended by terminal triplet methyls. The difference in chemical shift of the methylene protons is indicative of their neighbour to $s p^{2}$ and/or $s p^{3}$ carbon systems. This conclusion was further recognized by ${ }^{13} \mathrm{C}$ NMR spectra, at where several confused ester carbonyls were located between $\delta$ 173-172, among with multi $s p^{2}$ carbons of olefinic ones between $\delta 132-127 \mathrm{ppm}$, and two $s p^{3}$ oxy signals of methines and methylenes $(\delta 69,62)$. Finally, numerous multi $s p^{3}$ signals for methylene and methyl carbons were observed between $\delta 34-14 \mathrm{ppm}$. Based on such NMR spectroscopic data, and comparison with authentic spectra, the compound's structure of (1) was assigned as triglyceride fatty acids mixture.

\section{(9Z,12Z)-9,12-octadecanoic acid; linoleic acid}

Compound KSPU4 (3) was obtained as low polar colourless oil, exhibiting an UV absorbance and stained blue by anisaldehyde/sulphuric acid. The observed blue colour reaction of compound (3) indicated it most likely as steroid or fatty acid. The ${ }^{1} \mathrm{H}$ NMR spectrum exhibited a $1 \mathrm{H}$ broad singlet $(\delta$ 9.0) of free aliphatic carboxylic acid group. In addition, and $4 \mathrm{H}$ multiplet $(\delta$ 5.43-5.25), representing two olefinic double bonds. Furthermore, a $2 \mathrm{H}$ triplet of methylene group ( $\delta 2.78$ ) adjacent most likely to $s p^{2}$ carbon, and triplet of two magnetically equivalent methylene groups $(4 \mathrm{H}, \delta 2.52)$ adjacent to $s p^{2}$ carbons were displayed. Alternatively, two multiplets of $4 \mathrm{H}(\delta 2.08$ and 1.63) of rather two methylene groups were observed. A broad singlet of 10 protons was observed ( $\delta 1.42-1.23)$, pointing to a side chain of 5 methylene groups. 
At the end, a triplet of $3 \mathrm{H}$ terminal methyl was observed at $\delta 0.85$. The ${ }^{13} \mathrm{C} / \mathrm{APT}$ NMR spectra of (3) exhibited a carbonyl $(\delta 180.1)$ of carboxylic acid, along with four $s p^{2}$ methine carbons, representing two olefinic double bonds ( $\delta$ 130.1 127.8), 12 overlapping $s p^{3}$ methylene carbons ( $\delta$ 31.5-22.5) and one methyl carbon $(\delta 14.0)$. The molecular weight of (3) was determined as 280 Dalton by El mass spectrum. In accordance, (9Z,12Z)-9,12-octadecanoic acid; linoleic acid (3) was recognized, which was further confirmed by comparison with an authentic one. Linoleic acid (3) is known as a constituent of most vegetable and animal fats and is used biosynthetically as essential fatty acid for the production of prostaglandin, and was frequently isolated from marine brown algae (Khotimchenko, 1998).

\section{Calotropoleanyl ester}

From the middle polar fraction III, compound (4) (KSPU6) as major colourless crystalline, was obtained. Based on the displayed NMR spectra $\left({ }^{1} \mathrm{H} /{ }^{13} \mathrm{C}\right)$, two possible 3-acetoxy triterpenes were purposed, calotropoleanyl ester (Ansari and Ali, 1999) (4) and 3 $\beta$-acetoxy-13(18)-ursen (Misra et al., 1984) (7). Comparison the spectral data with the corresponding literatures recognized the structure as calotropoleanyl ester (4). Compound (4) was previously isolated from roots of Vernonia cinerea, Calotropis procera and Scaevola spp., while we report it here to first time so far from Pumpkin Ripe Fruits (Cucurbita pepo L).

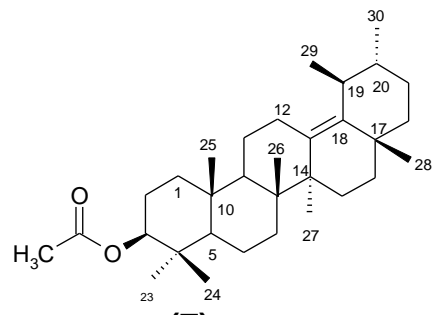

(7)

\section{Cholesterol}

Compound KSPU8 (5), as further colourless crystals, was afforded from the same fraction III by the same purification method for (4). After detailed interpretation of its spectroscopic data $\left({ }^{1} \mathrm{H} \&{ }^{13} \mathrm{C} N M R\right.$ and $\left.\mathrm{EI} \mathrm{MS}\right)$ and comparison with literature as well (Volkman et al., 1997 and Laatsch, 2007), the compound was deduced as cholesterol (5). Its alternative, 22dehydroclerosterol (8) was previously reported from giant pumpkin; cucurbita maxima (Akihisa et al., 1990).<smiles>C=C(C)C(/C=C/[C@H](C)[C@H]1CCC2C3CC=C4CC(O)CCC4(C)C3CCC21C)CC</smiles>

(8) 


\section{3(18)-oleanen-3-ol}

Finally, as rather colourless crystals, compound KSPU7 (6) was obtained from the last fraction IV. Compound (6) showed similar chromatographic properties to those of (4) showing pink colouration on spraying with anisaldehyde/sulphuric acid, with UV characteristics, as indicative of their structural closing. Alternatively, the compound was applied to spectroscopic assignments $\left({ }^{1} \mathrm{H} \&{ }^{13} \mathrm{C}\right.$ NMR, EI MS) pointing to further two alternatives; 13(18)-oleanen-3-ol ((He et al., 1998) (6) and 13(18)-ursen-3-ol(Misra et al., 1984) (9). According to the comparison with literatures, the compound was established as 13(18)-oleanen-3-ol (6). The compound (6) was previously reported from leaves of Bruguiera gymnorhiza, Spartium junceum and Cistus quadrangularis. Thereafter, compound (6) is reported here as a new structure from Pumpkin Ripe Fruits (Cucurbita pepo L).

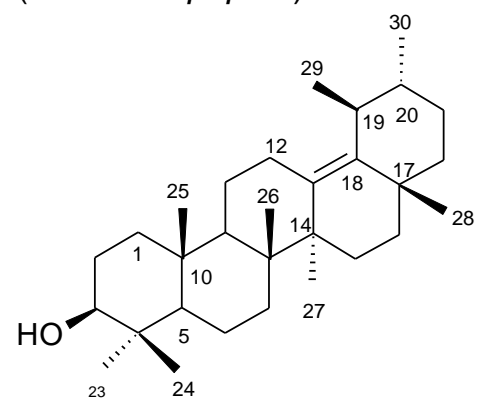

(9)

Biological Activities for Rind, Flesh and Seeds of Pumpkin.

\section{Antitumor activities:}

Extracts of the two constituted fractions of pumpkin (Rind and flesh) were consequently examined for in vitro cytotoxicity against the tumor cell lines each of Cervix carcinoma (HELA), Colon carcinoma (HCT116) and Intestinal carcinoma (CACO) (Table 4). All extracts displayed potent antitumor activities (fig 1 ) against Intestinal carcinoma (CACO) at I $\mathrm{C}_{50}$ ranged between 10.4 $14.0 \mu \mathrm{g}$. The two extracts appeared on the other hand potential cytotoxicity against Colon carcinoma (HCT116) at I $\mathrm{C}_{50}$ in the range of 06.79 08.77 $\mu \mathrm{g}$. The subjected Flesh extract exhibited the most potent $\left(\mathrm{IC}_{50}: 06.79 \mu \mathrm{g}\right)$ against HCT116, while the rind extract was the most potent against HCT116 ( $\left.\mathrm{IC}_{50}: 08.77 \mu \mathrm{g}\right)$. Contrarily, Flesh extract exhibited a lowest potential activity against HELA ( $\mathrm{IC}_{50}: 16.8 \mu \mathrm{g}$ ) followed by the Rind extract $\left(\mathrm{IC}_{50}: 16.0 \mu \mathrm{g}\right)$ as reported by National Cancer Institute.

Table 4: Antitumor activity of the pumpkin Rind \& Flesh against Cervix, Colon and Intestinal carcinoma cell lines (HELA, HCT116 \& CACO):-

\begin{tabular}{|c|c|c|c|}
\hline \multirow[t]{2}{*}{ Extract } & \multicolumn{3}{|c|}{ Cell lines } \\
\hline & HELA $\left(\mathrm{IC}_{50}, \mu \mathrm{g}\right)$ & HCT116 $\left(\mathrm{IC}_{50}, \mu \mathrm{g}\right)$ & CACO $\left(\mathrm{IC}_{50}, \mu \mathrm{g}\right)$ \\
\hline Rind & 16.00 & 08.77 & 14.00 \\
\hline Flesh & 16.80 & 06.79 & 10.40 \\
\hline
\end{tabular}




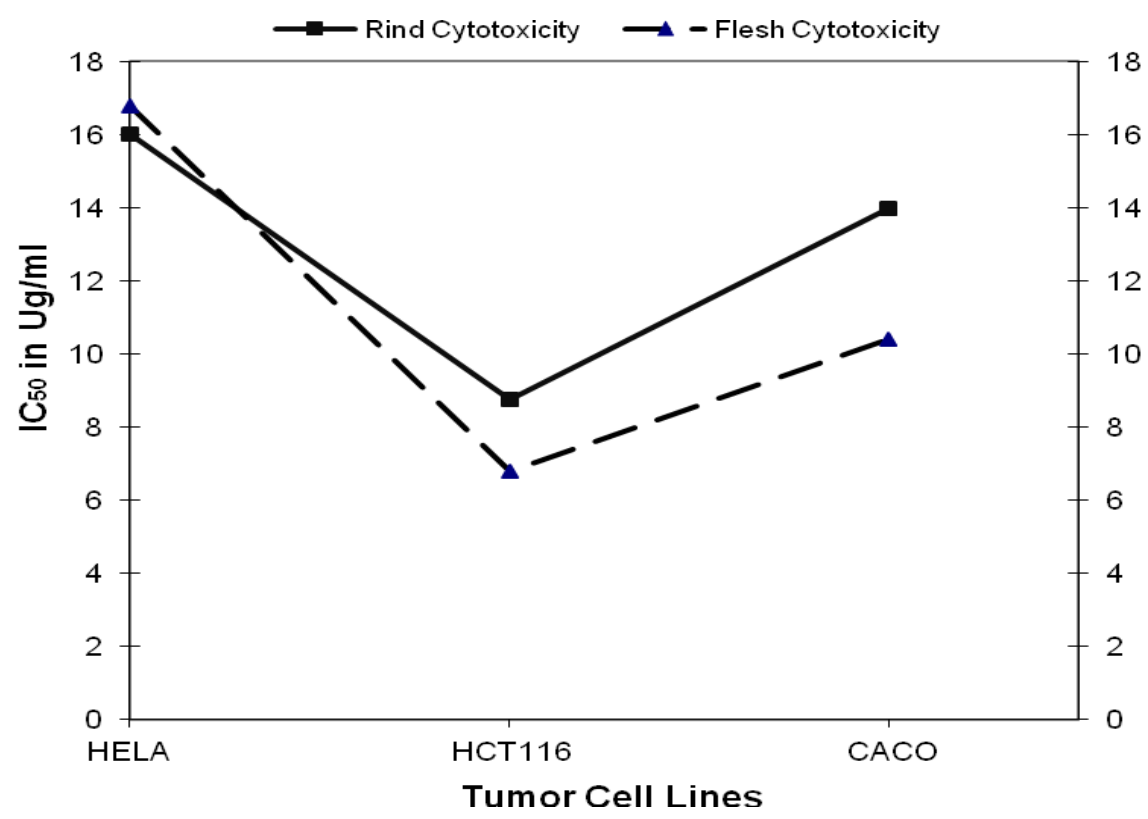

Fig.(1): Potential Cytotoxicity of the Pumpkin Rind flesh extracts using

Cervix, Colon and ntestinal carcinoma cell lines (HELA, HCT116 \& CACO) respectively.

In vivo Protein Quality for Pumpkin Defatted Seeds Meal.

Chemical score of amino acids for DSM's protein.

Amino acid score \% was calculated according to (FAO/WHO 1973) reference pattern (Table 5 ) to estimate first, second and third limiting amino acids for essential amino acids of Rind, Flesh and DSM of pumpkin as follow:-

\footnotetext{
$\mathrm{mg}$ of amino acids in $1 \mathrm{gm}$ tested protein Amino acid score $=\underline{\text { mof amino acids in requiement patern }} \times 100$

$\mathrm{mg}$ of amino acids in requirement pattern
} 
Badr, Sh.E.A. et al.

Table 5: The essential amino acids content for DSM of Pumpkin with those of FAO reference protein ( $\mathrm{mg} / \mathrm{gm}$ protein).

\begin{tabular}{|c|c|c|c|}
\hline \multirow[t]{2}{*}{ EAA's } & \multirow{2}{*}{$\begin{array}{l}\text { FAO reference } \\
\text { protein (1973) }\end{array}$} & \multicolumn{2}{|c|}{ DSM } \\
\hline & & AA & AAS \\
\hline Cys. + Meth. & 35.0 & 127 & 362.9 \\
\hline Iso. & 40.0 & 143 & 357.5 \\
\hline Leu. & 70.0 & 291 & 415.7 \\
\hline Lys. & 55.0 & 133 & $241.8^{a}$ \\
\hline${ }^{*}$ Phe. +Tyr. & 60.0 & 214 & $356.7^{c}$ \\
\hline Thr. & 41.0 & 126 & 307.3 \\
\hline Tryp. & 10.0 & 028 & $280.0^{b}$ \\
\hline Val. & 50.0 & 183 & 366.0 \\
\hline
\end{tabular}

According to (Alsmeyer et al., 1974), the four essential amino acids e.g, lysine, methionine, cysteine and tryptophan were estimated for the evaluation of protein quality. Since these are the EAA's found to be first limiting in most diets.

Data of (Table 5) illustrated that the amino acids score for DSM of Pumpkin where; the phenylalanine and lysine were the first limiting amino acids. Tryptophan was the second limiting amino acid. However, phenylalanine was the third limiting amino acid.

\section{3-2-2. True Digestibility, Biological Value and Net Protein Utilization for DSM.}

Table 6: The protein quality characters for DSM:-

\begin{tabular}{|c|c|c|c|}
\hline \multirow{2}{*}{ Sample } & \multicolumn{3}{|c|}{ Protein Quality Characters } \\
\cline { 2 - 4 } & True Digestibility & Biological Value & Net Protein Utilization \\
\hline Control & $79.52 \pm 0.86$ & $90.53 \pm 1.32$ & $71.99 \pm 1.4$ \\
\hline DSM & $70.32 \pm 1.12$ & $91.10 \pm 1.80$ & $64.06 \pm 1.2$ \\
\hline
\end{tabular}

The protein quality of the Pumpkin Defatted Seeds Meal "DSM" was assayed by animal feeding experiments and the data of the nitrogen balance is reported in (Table 6) and (Fig 2). A reference diet based on casein was studied at the same time as the diet based on the DSM. DSM showed a digestibility (70.32) lower than the similar one of casein (79.52) which means that 70.32 of the protein ingested was absorbed. It shows also no presence or minimum of the trypsin inhibitor which may reduce the susceptibility of the DSM protein to enzymatic hydrolysis. 


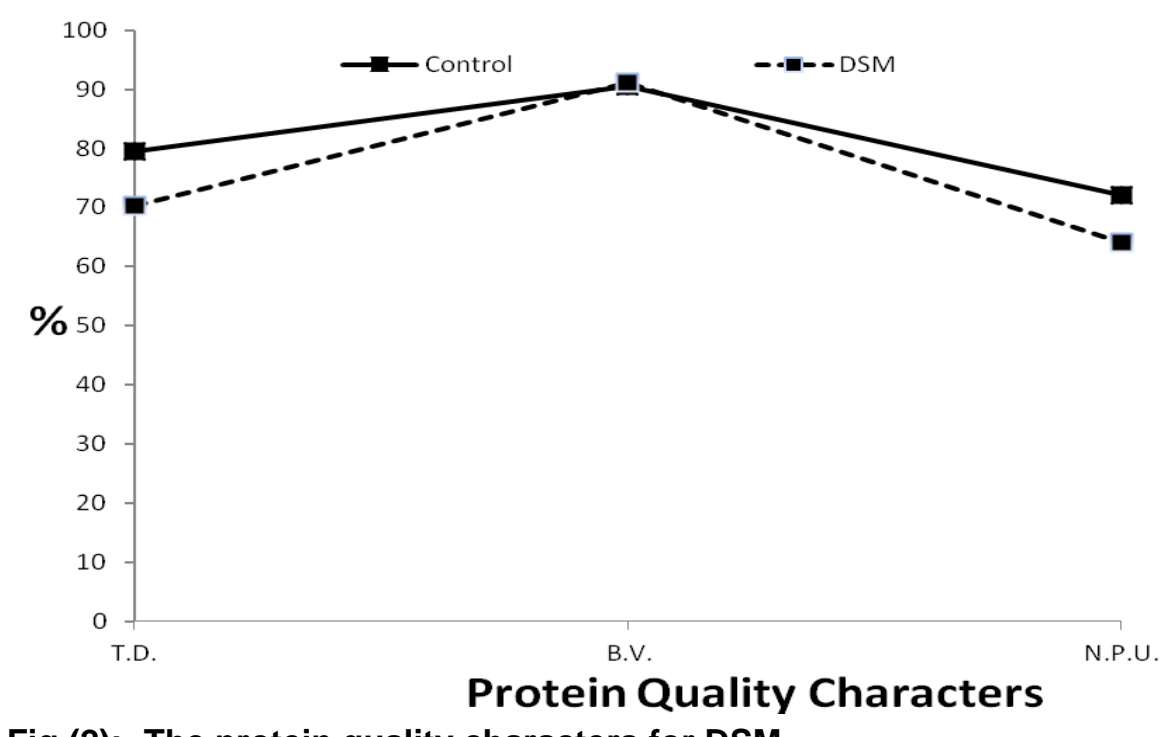

Fig (2):- The protein quality characters for DSM.

The Defatting Process applied to pumpkin seeds flour to prepare the DSM seems to have produced an increase of the digestibility in comparison to that obtained with (Jenny Ruales et al., 2002). The biological value of 91.1 obtained for the DSM showed that not all the protein absorbed was retained, has been reported. In addition, amino acid composition showed the phenylalanine and lysine were the first limiting amino acids, which might explain the relatively high biological value of the DSM than that of casein as the control which consider in contrast with that reported in (Jenny Ruales et al., 2002) assay. Due to the reducing in true digestibility of DSM than that obtained in case of casein, the net protein utilization of DSM is decreased may be in the same manner of (Jenny Ruales et al., 2002) non fat dried skimmed milk powder.

Validity of Rind, Flesh and Pumpkin Seeds Oil Extracts as Preserved Natural Organic Compounds.

The obtained results as reported in (Table 7) showed positive effects of pumpkin Rind and Flesh extracts as antimoulds as they increased the shelf life of the pan bread without any fungal growth. These effects are due to a protein called Pr-2 which has a direct effect on the fungal cell surface and positively inhibits some food and air bone fungi like Fusarium sp. and Trichoderma sp. These results agree with that obtained by (Park et al., 2009) who could identify the nature, sequences and modes of actions of Pr-2 from the two Pumpkin extracts and would proof their antifungal effects. 
Badr, Sh.E.A. et al.

Table 7: Effects of pumpkin Rind and Flesh extracts on fungal count on stored Pan Bread.

\begin{tabular}{|l|c|c|c|}
\hline & $\begin{array}{c}\text { Pan Bread treated } \\
\text { with Rind extract }\end{array}$ & $\begin{array}{c}\text { Pan Bread treated } \\
\text { with Flesh extract }\end{array}$ & $\begin{array}{c}\text { Not treated Pan } \\
\text { Bread "Control" }\end{array}$ \\
\hline $\begin{array}{l}\text { total fungal count of zero } \\
\text { time (cfu/g) }\end{array}$ & 0 & 0 & 0 \\
\hline $\begin{array}{l}\text { total fungal count of } 12 \\
\text { days (cfu/g) }\end{array}$ & 0 & 0 & $14 \times 10$ \\
\hline
\end{tabular}

cfu/g = colony forming units/gram.

\section{CONCLUSION}

Chromatographic purification of the extract afforded triglyceride fatty acid mixture (1), tetrahydro-thiophene (2) linoleic acid (3), calotropoleanly ester (4), cholesterol (5) and 13(18)-oleanen-3-ol (6). GC-MS analysis of the extract's unpolar fraction revealed the existence of dodecane and tetradecane. Rind, flesh and DSM of Pumpkin are talented sources of minerals. Pumpkin Defatted Seeds Meal "DSM", Rind and Flesh extracts contain several major groups of active constituents of essential amino acids, minerals and $\beta$-carotene especially the last for Flesh extract. The pumpkin Flesh and Rind extracts have highly potential cytotoxicity activity on the Colon, Intestinal and Cervix tumor cell lines as well as; they can use as preserve agents against fungus growing and increase the shelf time toward food poising. Owing to the protein quality of pumpkin seeds, they can be consumed as food or as supplementary ingredients especially in Egypt to alleviate the problems of health and nutrients/protein malnutrition. Further works are needed to evaluate not only the nutritional values for Rind, Flesh extracts and DSM but also; pharmacological investigations by using in vivo tests.

\section{REFERENCES}

Akihisa T., T. Tamura, T. Matsumoto, D. S. Eggleston, W. C. M.C. Kokke (1988) "Karounidiol [D:C-friedo-oleana-7,9(11)-diene-3a,29-diol] and its 3-O-benzoate: novel pentacyclic triterpenes from Trichosanthes kirilowii. X-ray molecular structure of karounidiol diacetate" JCS perkin I, 439-43.

Alsmeyer R. H., Cunningham A. E. And M. L. Happich (1974).Equations predict PER (Protein Efficiency Ratio) from amino acids analysis. Food Technol. (7): 34-42.

Ansari, S.H. and M. Ali (1999) "New oleanene triterpenes from root bark of Calotropis procera" J. Med. Aromat. Plant Sci., 21 , 978-981.

A.O.A.C. (1980). Official methods of analysis,11th Ed.,WILLIAMHORWITZ Edv., Washington D.C.

A.O.A.C. (2000). Association of Official Agriculture Chemists. Official Methods of Analysis. 17th ed., Washington D.C. USA. Chapter 4. 969.3 and 991.39 fatty acids in Oils and Fats preparation of Methyl Esters Boron Tri- Flouride- AOAC-IUPAC Method Codex- Adopted- AOAC Method. Chapter 41, pp 19- 20. 
A.O.A.C. (2002). Association of Official Agriculture Chemists. Official Methods of Analysis. $17^{\text {th }}$ ed., Washington D.C. USA.Vol. 1, P 40-41.

A.O.A.C. (2005). Association of Official Agriculture Chemists. Official Methods of Analysis. 18 $8^{\text {th }}$ ed., Washington D.C. USA. EZ Chrom (software used for data collection and processing), Eppendorf LC 3000, Revision 1, 2006.

Brian A. N. (2002). Resources for Home Preserving Pumpkins. National Center For Home Food Preservation, Department of Agriculture and supporting organizations, College of Agricultural and Environmental Sciences University of Georgia, U.S.pp1- 6.

Britton, G., S. Liaaen-Jensen, and H. Pfander. (1995). Carotenoids today and challenges for the future. In: Britton, G., S. Liaaen-Jensen, and $H$. Pfander [eds], Carotenoids vol. 1A: Isolation and Analysis. Basel: Birkhuser.

Chavasit V., Pisaphab R., Sungpuag P., Jittinandana S. And Wasantwisut E. (2002) "Changes in $\beta$-carotene and vitamin A contents of vitamin Arich foods in Thailand during preservation and storage" Journal of Food Science, 67, 375-379.

C S, NCl (2004) Cancer Statistics, National Cancer Institute, Department of Biostatistics \& Epidemiology NCl Egypt, December 2005.

Eggum BO. (1973). Nutritional Evaluation Of Protein By Laboratory Animals. In Evaluation of Novel Protein Products. Eds Bender, et al. Persimmon.

Eggum B. (1991): Comment on report of a joint FAO/WHO. Expert Consultation on Protein Quality. Rome 1990. Z.Ernaarungswiss, 39, 80- 90.

El-Adawy T.A. and Taha K.M. (2001). Characteristics and composition of different seed oils and flours. Food Chem. 74: 47-54.

EL-Soukkary, F. A. (2001). Evaluation of pumpkin seeds products for bread fortification. Plant Foods Hum. Nutr., 56(4):365- 384.

FAO / WHO, (1973). Food and Agricultural Organization./World Health Organization. Energy and protein requirements. Report of FAO nutrition meeti series No. 52, Rome.

FAO / WHO, (2007). Food and Agricultural Organization./World Health Organization. "Protei and amino acids requirements in Human Nutration. WHO Press. Page 150.

Giami, S.Y., Achinewhu S.C. and Ibaakee C. (2005). The quality and sensor Attributes of cookies supplemented with fluted pumpkin (Telfairia occidentalis Hook) seed flour. In. J. Food Sci.Technol., 40: 613-620.

Gouado I., Aba Ejoh R.T. Somé I., Florian J. Schweigert and M.F.T chouanguep. (2007).Carotenoids Content of Some Locally Consumed Fruits and Yams in Cameroon. Pakistan Journal of Nutrition 6 (5): 497501.

Hamed. S. Y., N. M. El Hassan, A. B. Hassan, M. M. Eltayeb, E. E. Babiker. (2008). "Nutritional Evaluation and Physiochemical Properties of Processed Pumpkin (Telfairia occidentalis Hook) Seed Flour" Pakistan Journal of Nutrition, 7, 330-334.

He A., Wang M., Hao H., Zhang D. and Lee K-H. (1998) "Hepatoprotective triterpenes from Sedum sarmentosum" Phytochemistry, 49, 2607-2610. 
Iva J., Patrick B. and Lse S. (2003). Determination of trace elements in pumpkin seed oils and pumpkin seeds by ICP-AES. J. Anal. At. Spectrum., 18, 54- 58.

Jenny Ruales, Yolanda de Grijialva, Patricio Lopez- Jaramillo and Baboo M.Nair. (2002). The nutritional quality of an infant food from quinoa and its effect on the plasma level of insulin- like growth factor-1 (IGF-1) in undernourished children. International journal of food Sciences and Nutrition. 53: 143- 154.

Jia Wei; Gao Wenyuan; Tang Lida (2003)" Antidiabetic herbal drugs officially approved in China." Phytotherapy research: PTR, 17(10), 1127-34.

Khotimchenko S. V., (1998) Phytochemistry, 49, 2363-2369.

Laatsch H. AntiBase (2007), A Data Base for Rapid Dereplication and Structure Determination of Microbial Natural Products, Wiley- $\mathrm{VCH}$ Weinheim, Germany; seehttp:// www user. gwdg.de/ ucoc/laatsch/Anti Base .htm.

Leth, T. and Jacobsen J.S. (1993). Vitamin A in danish pig, calf and ox liver. J. Food Comp. Anal. 6: 3- 9.

Misra T. N., R. S. Singh, J. Upadhyay, R. Srivastava (1984) "Chemical constituents of Vernonia cinerea, part I. Isolation and spectral studies of triterpenes" J. Nat. Prod., 47, 368-72.

Mohamed A.- L. I., Mohamed A. I. and Mansour A. M. (2003). SOLAR DRYING. A thesis submitted to the Faculty of Engineering at Al- Azhar University. In Partial Fulfillment of the Requirements for the degree of Doctor of Philosophy in Mechanical Power Engineering.

N.M.K.L. (2005) Nordic Committee on food analysis (NMKL), Report No. 98, ed. Enumeration of moulds and yeast in food and feed.

Park S.C.; J.Y. Kim, J.K. Lee, I. Hwang, H. Cheong, J.W. Nah, K.S. Hahm and Y. Park (2009) Antifungal Mechanism of a Novel Antifungal Protein from Pumpkin Rinds against Various Fungal Pathogens, J. Agric. Food Chem., 57 (19), pp 9299- 9304

Sara Y. H., Nafisa M. E. H., Amro B. H., Mohamed M. E. And Elfadil E. B. (2008). Nutritional Evaluation and Physiochemical Properties of Processed Pumpkin (Telfairia occidentalis Hook) Seed Flour. Pakistan Journal of Nutrition 7 (2): 330-334.

SKehan P., Storeng R., et al. (1990). "New colormetric cytotoxicity assay for anti-cancer drug screening". J. Natl. Cancer Inst. 82: 1107-1112.

Sudhakar P., Jagdish S., Upadhyay A.K., Ram D.and Mathura R. (2003). Ascorbate and Carotenoid Content in an Indian Collection of Pumpkin (Cucurbita moschata Duch. ex Poir.). Indian Institute of Vegetable Research, 1, Gandhi Nagar (Naria),Cucurbit Genetics Cooperative Report 26:51-53.

Volkman, J.K., Farmer, C.L., Barrett, S.M., \& Sikes, E.L. (1997). Unusual dihydroxysterols as chemotaxonomic markers for microalgae from the order Pavlovales (Haptophyceae). Journal of Phycology, 33, 10161023.

Wade, P. (1988). Biscuits, Cookies and Crackers Vol, 1. Recipe of biscuit used during investigation. (1): 102-114. Applied Science Puplishers LTD, London, Uk. 
West, C., Ans E. and Van L.M. (2002). Consequences of revised estimates of carotenoids bioefficacy for dietary control of vitamin A deficiency in developing countries. J. Nutr., 132: 2920S-2926S.

Yusuf,A. A., Folarin, O. M. and Bamiro, F. O. (2007). Chemicalcomposition And functional properties of snake gourd (Trichosanthes cucumerina) seed flour. Nigerian Food Journal, Vol. 25, No. 1, pp. 36-45.

Zhu, K. X., H. M. Zhou and H. F. Qian (2006). Proteins extracted from defatted wheat germ: Nutritional and structural properties. Cereal Chemi., 83 (1):69-75.

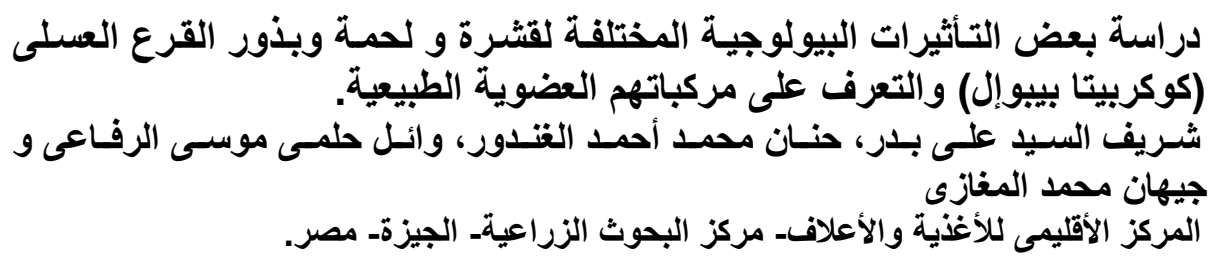

تم دراسة التركيب الكيميائي والتأثير البيولوجي لقتر ولحمة وبذور القرع العسلي ( كوكر بيتا

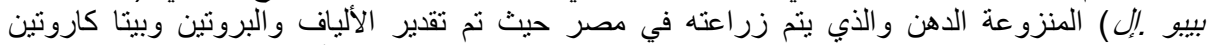

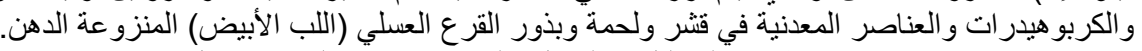

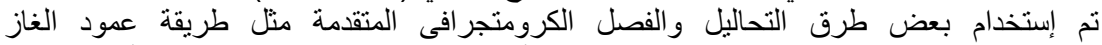

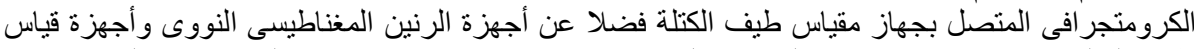

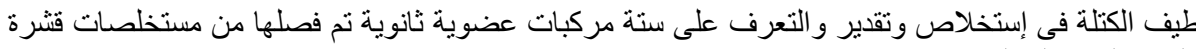

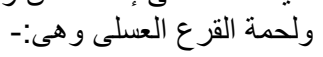

Triglyceride fatty acid mixture, tetrahydro-thiophene, linoleic acid, calotropoleanly ester, cholesterol and 13(18)-oleanen-3-ol.

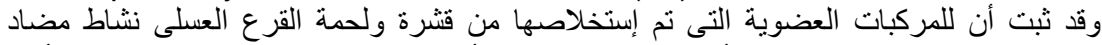

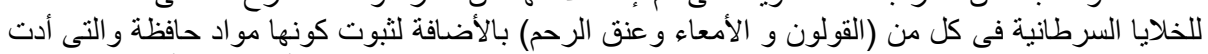

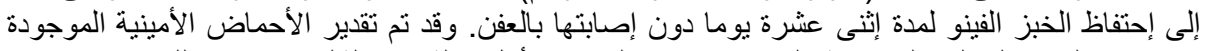

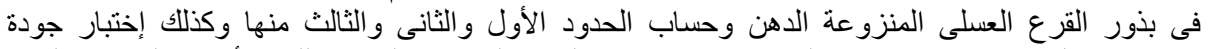

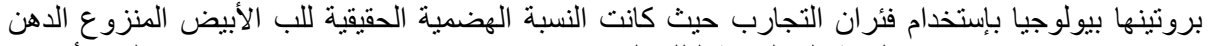

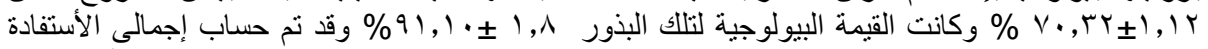

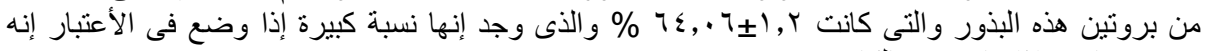
مصدر نباتى و إذا ما قورن بالكازين.

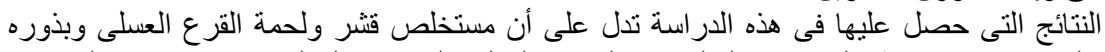

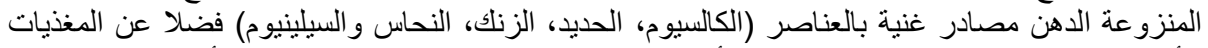

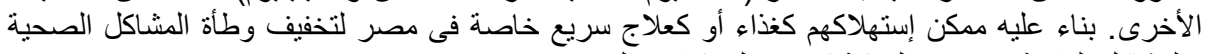

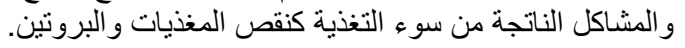

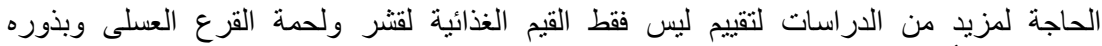

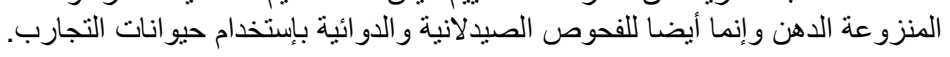

كلية الزراعة - جامعة المنصورة كلية العلوم - جامعة جلوة حلوان

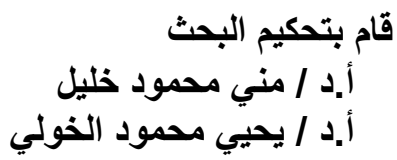


Badr, Sh.E.A. et al. 